\title{
PERTIMBANGAN HAKIM DALAM PENYELESAIAN SENGKETA HARTA WARIS ANTARA SAUDARA KANDUNG
}

\author{
MASNAYANTI, ABDILLAH MUSTARI
}

Fakultas Syariah dan Hukum Universitas Islam Negeri Alauddin Makassar

\begin{abstract}
Abstrak
Konsep pembagian harta waris dalam hukum Islam terbagi dalam beberapa bagian yaitu Hukum bagian waris untuk anak, Hukum Bagian Warisan untuk Orang Tua, Hukum Bagian Waris untuk Duda atau Janda, Hukum Bagian Waris untuk Saudara Seibu Lain Ayah, Hukum Bagian Waris untuk Saudara Sekandung atau Seayah, Bagian Waris Áṣabah al-furuḍ, Bagian Ahli Waris Áṣabah. Adapun dalam memutuskan perkara hakim memiliki dasar pertimbangan dalam menyelesaikan perkara sengketa harta waris antara saudara kandung, adapun dasar pertimbangan tersebut secara keseluruhan berpatokan kepada Hukum Islam (kewarisan). Adapun dasar pertimbangan tersebut pada sengketa harta waris antara saudara sekandung, tidak menemui kendala dikarenakan dalam penyelesaian sengketa tersebut diselesaikan secara kekeluargaan.
\end{abstract}

Kata Kunci : Harta Waris, Pertimbangan Hakim, Saudara Kandung, Sengketa.

\begin{abstract}
The concept of division of inheritance in Islamic law is divided into several parts, namely inheritance law for children, inheritance law for parents, inheritance law for widowers or widows, inheritance law for siblings, fatherhood, inheritance law for siblings or father, Section of Inheritance of Ásabah al-furu, Section of Heirs of Ásabah. As for deciding the case of a judge has a basis for consideration in resolving cases of inheritance disputes between siblings, while the basis for these considerations is based entirely on Islamic Law (inheritance). The basis for these considerations in inheritance disputes between siblings, doesn't encounter obstacles because in the settlement of the dispute is settled in a family.
\end{abstract}

Keywords: Disputes, Inheritance, Judge Considerations, Siblings. 


\section{A. PENDAHULUAN}

Sejak Undang-Undang Dasar Negara Republik Indonesia tahun 1945 di berlakukan pertama kali pada tanggal 18 agustus 1945, bangsa Indonesia telah memiliki kesadaran akan konsep Negara Hukum sebagai pilihan yang ideal bagi Negara Indonesia yang diproklamasikan satu hari sebelumnya, yaitu pada tanggal 17 agustus $1945 .{ }^{1}$

Konsep Negara hukum dapat diasalkan pada gagasan-gagasan pencerahan mengenai kedaulatan manusia dalam menentukan jalan kehidupan sosialnya.Manusia dalam pengertian kebertahapan, bergerak dari individu menuju relasi sosial sehingga hukum dalam makna yang lebih tegas adalah sistem yang dihasilkan dari sebuah kesepakatankesepakatan ataupun kosensus-konsensus yang lazim disebut kontrak sosial (Social Contract). Dalam pengertian ini, kekuasaan bersumber dari hukum yakni kesepakatan sosial.Dengan demikian kedaulatan dalam negara ada pada hukum yang seluruh entitas politik, sosial, dan ekonomi dibawahnya tunduk pada hukum tersebut. ${ }^{2}$

Indonesia merupakan Negara yang tidak terlepas dari hukum. Salah satu bentuk hukum yang diterapkan di Indonesia dalam rangka mengatur hubungan hukum antara masyarakat Indonesia adalah hukum Islam.

Hukum Islam merupakan satu kesatuan sistem hukum. Hukum Islam merupakan hukum yang bersumber dari Al-Quran dan Al-Hadist yang mengatur segala perbuatan hukum bagi masyarakat yang menganut agama Islam, salah satunya adalah mengenai kewarisan. Karena kewarisan pada dasarnya merupakan bagian yang tak terpisahkan dari hukum, sedangkan hukum adalah bagian dari aspek ajaran Islam yang pokok.

"Justice is the core of law. However, the barometer of justice based on human's consideration always changes according to time and place (tagayyur al-ahkam bi altagayyir al-azminah wa al-amkinah). The concept of legacy portion between man and woman, 2:1 in surah An-Nisa verse 11-12 always become a problem espaciallywhen it is viewed from the equality of right and gender. Hence, the philosophy of Islamic law is then considered as an alternative to solve the problem. According to distributive justice perspective the legacy portion of 2:1 is fair since it iscommensurate with the responsibility and the righ of both sides. It relates to the duty of a husband to take care of his parents after getting married. If then the woman take over the responsibility or do the same, it still do not change the portion. The problem above may be overcome throughnthe concept of al-ahliyah al-wujub in order to share the portion equally between man and woman".

Keadlian merupakan masalah yang sering sekali muncul dibalik sebuah hukum. Hal ini dikarenakan, tolak ukur dari sebuah keadilan manusia yang selalu berubah, sesuai dengan waktu dan tempat (tagyyir al-ahkam bi al-tagayyur al-azminah wa al-amkinah). Konsep keadilan pembagian harta waris 2:1 antara laki-laki dengan perempuan dalam Qs. An-Nisa (4) 11-12 selalu menjadi problem, apalagi dibandingkan kondisi sosial sekarang yang menjunjung tinggi kesamaan hak dan gender. Oleh karena itu, perlu pendekatan filsafat hukum Islam dalam mengkaji permasalahan ini. Dalam prespektif keadilan distributif, pembagian kewarisan dalam Islam (2:1 antara laki-laki dengan perempuan sudah adil, karena sesuai dengan bagian yang propesional antara hak dan kewajiban antara keduanya. Konsep keadilan tersebut dapat dikaitkan dengan ketentuan

${ }^{1}$ Yayasan Lembaga Bantuan Hukum, Bantuan Hukum Bukan Hak Yang Diberi, (Cet. I; Jakarta Pusat :YLBHI, 2013), h. 1.

${ }^{2}$ Fajlurrahman Jurdi, Teori Negara Hukum, (Malang: Setara Press, 2016), h. VII. 
tentang hak dan kewajiban suami istri dalam hukum perkawinan dan kewajibannya seorang anak laki-laki pengurusan dan pemeliharaan orang tuanya setelah berumah tangga. Kalaupun terjadi perubahan sosial, misalnya wanita bekerja/karir, maka persentasenya kecil dan bersifat kasuistik, tidak dapat membatalkan hukum yang bersifat umum. Permasalahn sosial yang bersifat kasuistik ini dapat menggunakan konsep alahliyah al-wujub dalam memberikan kesamarataan pembagian warisan antara laki-laki dengan perempuan. ${ }^{3}$

Hukum waris Islam pada dasarnya mengatur hal yang sama dengan hukum waris pada umumnya (hukum waris Barat dan hukum waris Adat), yaitu mengatur tentang pembagian harta peninggalan dari seseorang yang telah meninggal dunia.

Dalam Hukum Islam, hukum waris mempunyai kedudukan yang amat penting. Hal ini dapat dimengerti karena masalah kewarisan akan dialami oleh setiap orang. Dimana Hukum kewarisan merupakan bagian dari hukum kekeluargaan yang memegang peranan yang penting, bahkan menentukan dan mencerminkan sistem dan bentuk hukum yang berlaku dalam masyarakat. Hal ini disebabkan karena hukum kewarisan itu erat kaitannya dengan ruang lingkup kehidupan manusia, bahwa setiap manusia pasti akan mengalami peristiwa, yang merupakan peristiwa hukum dan lazim disebut meninggal dunia. Apabila ada sesuatu peristiwa hukum, yaitu meninggalnya seseorang akan sekaligus menimbulkan akibat hukum, yaitu tentang bagaimana pengurusan atau kelanjutan hak-hak dan kewajiban seseorang yang meninggal dunia. Penyelesaian hakhak dan kewajiban sebagai akibat adanya peristiwa hukum karena meninggalnya seseorang diatur dalam hukum kewarisan.

Hukum kewarisan adalah hukum yang mengatur tentang pemindahan hak pemilikan harta peninggalan (tirkah) pewaris, menentukan siapa-siapa yang berhak menjadi ahli waris dan berapa bagian masing-masing. ${ }^{4}$

Adapun pngertian hukum waris dalam KUHPerdata adalah hukum-hukum atau peraturan-peraturan yang mengatur, tentang apakah dan bagaimanakah pelbagai hak-hak dan kewajiban tentang kekayaan seseorang pada waktu meninggal dunia akan beralih kepada orang lain yang masih hidup. ${ }^{5}$ Jadi Hukum Kewarisan itu dapat pula dikatakan sebagai himpunan peraturan hukum yang mengatur bagaimana caranya pengurusan hakhak dan kewajiban seseorang yang meninggal dunia oleh ahli waris atau badan hukum lainnya.

Istilah waris sudah dikenal oleh masyarakat Indonesia, sehingga kebanyakan masyarakat Indonesia mengartikan Ilmu Waris sebagai suatu perpindahan hak dan kewajiban serta harta kekayaan seseorang yang meninggal dunia kepada orang lain yang masih hidup. Selain itu masalah warisan merupakan suatu masalah yang sangat mudah untuk menimbulkan sengketa atau perselisihan diantara ahli waris atau dengan pihak ketiga.

${ }^{3}$ M. lutfi Hakim, Jurnal Keadilan Kewarisan Islam Terhadap Pembagian Waris 2: 1 Antara Laki-Laki Dengan Perempuan Perspektif Hukum Islam”, h. 1 (lutfyhakim@gmail.com) 339-1112-1 PB.pdf (8-12-2017).

${ }^{4}$ Istiqamah, Hukum Waris dan Benda, (Makassar: Alauddin University Press, 2012), h. 7.

${ }^{5}$ Abdillah Mustari, Hukum Waris Perbandingan Hukum Islam Dan Undang-Undang Hukum Perdata Barat, (Cet. I; Makassar: Alauddin University Press), h. 4. 
Masalah-masalah yang menyangkut warisan seperti halnya masalah-masalah lain yang dihadapi manusia ada yang sudah dijelaskan permasalahannya dalam Al- Quran. Salah satu contohnya sebagaimana dijelaskan dalam Qs.Al-Ahzab (33):27, yaitu

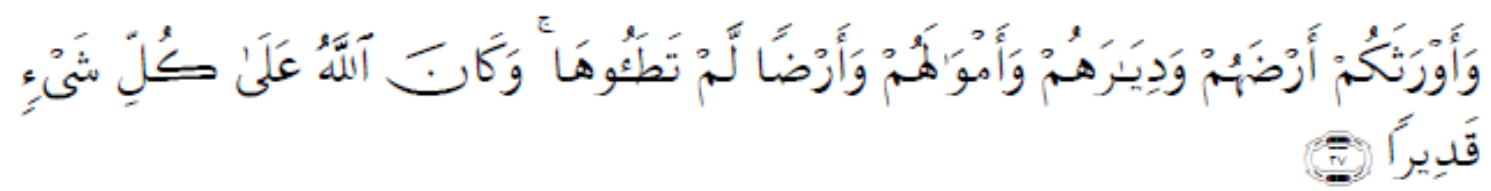

Terjemahannya:

"Dan dia mewariskan kepada kamu tanah-tanah, rumah-rumah dan harta benda mereka, dan (begitu) tanah yang belum kamu injak. Dan adalah Allah Maha Kuasa terhadap segala sesuatu."6

Menurut Kompilasi Hukum Islam, ahli waris adalah orang yang pada saat meninggal dunia mempunyai hubungan darah dan hubungan perkawinan dengan pewaris, beragama Islam, yang dimaksud ahli waris adalah mereka yang jelas-jelas mempunyai hak waris ketika pewarisnya meninggal dunia, tidak ada halangan untuk mewaris.

Selain dari ayat tersebut, undang-undang juga mengatur tentang kewarisan dalam Pasal 852 KUHPerdata/BW bahwa anak-anak atau keturunan-keturunan, sekalipun dilahirkan dari berbagai perkawinan, mewarisi harta peninggalan para orangtua mereka, kakek dan nenek mereka, atau kelurga-keluarga sedarah mereka selanjutnya dalam garis lurus keatas, tanpa membedakan jenis kelamin yang lebih dulu.

Dalam Kompilasi Hukum Islam diatur tentang kewarisan dalam Pasal 171 yang mana ada beberapa ketentuan mengenai kewarisan, yaitu:

1. Hukum kewarisan adalah hukum yang mengatur tentang pemindahan hak pemilikan harta peninggalan (tirkah) pewaris, menentukan siapa-siapa yang berhak menjadi ahli waris dan berapa bagiannya masing-masing;

2. Pewaris adalah orang yang pada saat meninggal berdasarakan putusan Pengadilan beragama Islam, meninggalkan ahli waris dan harta peninggalan;

3. Ahli waris adalah orang yang pada saat meninggal dunia mempunyai hubungan darah atau hubungan perkawinan dengan pewaris, beragama Islam dan tidak terhalang karena hukum untuk menjadi ahli waris.

4. Harta peninggalan adalah harta yang ditinggalkan oleh pewaris baik yang berupa harta benda yang menjadi hak miliknya maupun hak-haknya.

5. Harta warisan adalah harta bawaan ditambah bagian dari harta bersama setelah digunakan untuk keperluan pewaris selama sakit sampai meninggalnya, biaya pengurusan jenazah, pembayaran hutang dan pemberian untuk kerabat.

Berbagai perkawinan, mewarisi harta peninggalan para orang tua mereka, yang berhak menjadi ahli waris ialah keluarga sedarah, baik yang sah menurut undang-undang maupun yang di luar perkawinan, dan suami atau isteri yang masih hidup, menurut peraturan-peraturan berikut ini. Bila keluarga sedarah dan suami atau isteri sudah meninggal, maka semua harta peninggalan menjadi milik negara, yang wajib melunasi utang-utang orang yang meninggal tersebut, sejauh harga harta peninggalan mencukupi untuk itu. Karena dalam hukum kewarisan ada tiga unsur pokok yang saling terkait yaitu pewaris, harta peninggalan, dan ahli waris. Dalam permasalahan ini muncul satu

${ }^{6}$ Kementerian Agama RI, Al-Qur'an dan Terjemahannya, (Solo: PT. Tiga Serangkai, 2014), h. 421.

${ }^{7}$ Mardani, Hukum Kewarisan Islam di Indonesia, (Jakarta: Rajawali Pers,2015), h. 35. 
pertannyaan bahwa jika tidak ada ahli waris maka pembagian harta warisan diberikan untuk siapa, maka dari permasalahan tersebut penulis berinisiatif mengambil judul tentang "Dasar Pertimbangan Hakim Dalam Penyelesain Sengketa Harta Waris Antara Saudara Kandung Di Pengadilan Agama Sungguminasa Kelas I B.

Pengadilan Agama Sungguminasa merupakan salah satu lembaga peradilan yang berada di bawah Mahkamah Agung yang berfungsi sebagai lembaga yang memutuskan, menyelesaikan perkara Perdata khususnya perkara kewarisan.

\section{B. METODE PENELITIAN}

Jenis penelitian yang digunakan adalah field research atau penelitian lapangan dengan menggunakan salah satu metode pengumpulan data dalam penelitian kualitatif dengan menggunakan pendekatan sosiologis (sosiological approach) dan pendekatan syar'i. Sumber data dalam penelitian ini adalah sumber data primer yaitu turun langsung kelapangan dan data sekunder melalui studi kepustakaan. Selanjutnya metode pengumpulan data menggunakan analisis kualitatif atau data yang dikumpulkan bersifat deskriptif dalam bentuk kata-kata atau gambar.

\section{PEMBAHASAN}

1. Dasar Pertimbangan Hakim dalam Memberikan Putusan Pada Sengketa Harta Waris antara Saudara Kandung di Pengadilan Agama Sungguminas Kelas 1 B.

Tujuan suatu proses di persidangan adalah untuk memperoleh putusan hakim yang berkekuatan hukum tetap. Sesuai dengan ketentuan pasal 178, apabila pemeriksaan perkara selesai, majelis hakim karena jabatannya melakukan musyawarah untuk mengambil putusan yang akan dijatuhkan. Yang dimaksud dengan proses pengambilan keputusan ialah proses sejak dilimpahkannya perkara ke Pengadilan, pemeriksaan dalam sidang pengadilan sampai diputusnya suatu perkara. Dengan kata lain suatu proses yang dilalui suatu perkara sejak pelimpahannya sampai diperolehnya putusan pengadilan atas perkara teresebut. Setelah semua tahap pemeriksaan persidangan terselesaikan, majelis hakim menyatakan pemeriksaan ditutup dan proses selanjutnya adalah menjatuhkan atau pengucapan putusan. ${ }^{8}$

Dalam memutuskan suatu perkara seorang hakim harus mempunyai dasar pertimbangan terlebih dahulu. Adapun pengertian dasar sebagaimana hasil wawancara yang telah dilakukan yaitu kalau bicara dasar berarti aturan-aturan yang kami terapkan dalam perkara. Adapun pertimbangan hakim merupakan salah satu aspek terpenting dalam memutuskan suatu perkara agar terwujud suatu nilai dari putusan hakim yang mengandung keadilan (ex aequo et bono) dan mengandung kepastian hukum, di samping itu juga mengandung manfaat bagi para pihak yang bersangkutan sehingga pertimbangan hakim ini harus disikapi dengan teliti, baik, dan cermat. Apabila pertimbangan hakim tidak teliti, baik, dan cermat, maka putusan hakim yang berasal dari pertimbangan hakim tersebut akan dibatalkan oleh Pengadilan Tinggi/Mahkamah Agung. ${ }^{9}$

Pertimbangan yang diambil oleh hakim dalam menangani perkara atau kasus kewarisan dapat dilihat dari hasil penelitian yang telah dilakukan yaitu:

\footnotetext{
${ }^{8}$ Harun M.Husein, Kasasi sebagai Upaya Hukum, (Jakarta: Sinar Grafika, 1992), h. 16.

${ }^{9}$ Mukti Arto, Praktek Perkara Perdata pada Pengadilan Agama, cet V (Yogyakarta: Pustaka Pelajar, 2004), h.140.
} 
"Kalau bicara dasar yang kami terapkan dalam perkara khususnya kewarisan selama ini menangani perkara-perkara kewarisan pada intinya berkaitan dengan perkara hubungan keluarga. Kalau persoalan kewarisan kita lihat dulu siapa yang jadi ahli waris, harta peninggalannya, kalau pewaris kita lihat kejadian dari meninggalnya yang memberi warisan dan kapan dia meninggal. Jadi pewaris kita lihat dari hubungannya yang ditinggalkan seperti suami, ada istri, anak, bapak, ibu. Kalau misalnya: suami yang meninggal belum membagi harta waris, istri, anak, bapak dan ibu. Saudara kandung terjadi orang tuannya meninggal dunia 2 laki-laki, 4 perempuan tidak ada kakek dan nenek, misalnya kalau 2 perempuan dan 4 lakilaki berarti menghalangi kerabat mendapatkan warisan. Kalau ada anak laki-laki berarti paman tidak dapat, bapak juga tidak dapat, saudari ibu juga tidak dapat karena mereka terhalang adanya anak laki- laki. Kalau misalnya anak perempuan itu bisa jadi paman bisa dapat. Pemahan. masyarakat kalau ada anak berarti bisa menghalangi kerabat mendapatkan warisan. Dilihat lagi dari jenisnya, kalau ada laki-laki terhalang semua, jika perempuan tidak bisa menhabisi kecuali sudah dibicarakan. Yang memjadi ashabah itu tidak ada dari perempuan yang ada dari laki-laki, сисu, kakek. Kalau saudara kandung ditinggalkan itu rumah ditaksir sekitar 1 M kemudian yang menguasai anak pertama misalnya, laki-laki dia tidak memberikan saudaranya. Ini lah yang akan dibahas kalau ada yang merasa keberatan bisa digugat. Sekarang hakim tugasnya adalah minimal menggali apa ini benar harta waris. Kalau yang ini bisa membuktikan kalau itu betul-betul harta waris. Berarti hakim harus menentukan pewaris siapa dan ahli warisnya siapa, kemudian harta yang ditinggalakan apakah harta peenikahan. Dasar pertimbangan kita tetap mengacu pada hukum Islam bagian kewarisan. Kalau ada perdamaian bisa juga 1:1, kalau Islam 2:1, perdata bisa bagi rata 1:1."10

Adapun terkait persoalan sengketa antar saudara menurut hakim dalam penyelesaiannya tidak menemui kendala karena pada umumnya hakim tetap memakai sistem kekeluargaan. Hal ini sesuai dengan hasil penelitian yang telah dilakukan oleh peneliti yaitu:

"Dalam memutuskan perkara sengketa ahli waris, hakim secara umum itu tidak ada kendala, karena hakim tetap mengutamakan sistem kekeluargaan dalam menangani sengketa ahli waris, tidak perlu sacara real dibawa ke pengadilan, karena menyangkut persoalan waris itu bawahannya dapat berkepanjangan karena bergelut dengan sistem eksekusi. Apalagi pihak yang berperkara itu mengeluarkan biaya sendiri untuk kasus hukum yang ditempuh. Akan tetapi hakim tetap menjalankan sistem karena tidak boleh menolak perkara, oleh karena itu tetap mengedepankan sistem kekeluargaan."

2. Analisis Putusan Hakim Tentang Perkara Waris Antara Saudara Kandung Di Pengadilan Agama Sungguminas Kelas 1B (Putusan Nomor 271/Pdt.G/2017/PA Sgm)

Babang Bin Nuhung dan Basse Dg. Ngai mempunyai 5 anak yaitu:

1. Jawaria Dg. Ti'no Binti Babang Bin Nuhung (Penggugat I)

2. H. dg. Sirwa Bin Babang Bin Nuhung (Penggugat II)

3. Rukiyah Dg. Pajja Binti Babang Bin Nuhung (Penggugat III)

${ }^{10}$ Uteng Tahir, Hakim Pengadilan Agama Sungguminasa, Wawancara, Gowa, 15 November 2017. 
4. Nurdin Dg. Lawa Bin Babang Bin Nuhung (Tergugat I)

5. Suniati Dg. Sutta Binti Babang Bin Nuhung (Penggugat IV)

Babang Bin Nuhung meninggal dunia pada tanggal 15 September 1993 dan Basse Dg. Ngai juga telah meninggal dunia pada tanggal 1 April 2001. Sebagian dari harta mereka sudah terbagi namun penggungat mempermasalahkan objek warisan yang luas seluruhnya $\pm 2000 \mathrm{M}^{2}$ sebelum menjadi jalan, namun jalan $\pm 100 \mathrm{M}^{2}$ maka objek warisan tersebut sisa $\pm 1.900 \mathrm{M}^{2}$. Sisa harta tersebut dikuasai oleh tergugat dan menolak dengan tegas membagi sesuai dengan ketentuan Kompilasi Hukum Islam.

Adapun pertimbangan hakim dalam memutuskan perkara dengan pertimbangan bahwa berdasarkan pemahaman terhadap ketentuan pasal 176 Kompilasi Hukum Islam, maka ahli waris dari almarhum Babang bin Nuhung dan Besse Dg. Ngai adalah kelima anaknya tersebut. Pasal 1888 KUH Perdata mengatur tentang kekuatan pembuktian yang bisa ditunjukkan dalam pengadilan dan fotokopi yang tidak dapat ditunjukkan aslinya tidak dapat dijadikan sebagai alat bukti dalam hal ini penggungat menghadirkan 3 orang saksi. Pada pasal 171 ayat 4 Kompilasi Hukum Islam menyebutkan bahwa yang dimaksud dengan harta peninggalan adalah harta yang ditinggalkan oleh pewaris baik yang berupa benda yang menjadi miliknya maupun hak-haknya.

Sedangkan dalam pasal $570 \mathrm{KUH}$ Perdata menyebutkan bahwa yang dimaksud dengan hak milik adalah hak untuk menikmati kegunaan suatu benda dengan leluasa dan untuk berbuat bebas terhadap kebendaan itu dengan kedaulatan sepenuhnya sepanjang tidak bertentangan peraturan perundang-undangan yang berlaku dan tidak mengganggu hak-hak orang lain, dengan tidak mengurangi kemunkinan akan adanya pencabutan hak tersebut demi kepentingan umum berdasarkan atas ketentuan undang-undang dengan disertai pembayaran ganti rugi.

Sebelum mempertimbangkan mengenai gugatan rekonvensi, terlebih dahulu Majelis Hakim akan mempertimbangkan legalitas formil kuasa penggugat rekonvensi sebagai wakil atau kuasa untuk dapat berkedudukan dan bertindak mewakili penggugat materil selaku pemberi kuasa.

Setelah memeriksa dan meneliti dengan seksama surat kuasa tersebut, ternyata di dalam surat kuasa tersebut hanya menyebutkan hak penerima kuasa untuk mengajukan jawaban dan duplik tanpa menyebutkan hak penerima kuasa untuk mengajukan gugatan rekonvensi. Maka berdasarkan uraian pertimbangannya, pengadilan menyatakan gugatan penggugat tidak dapat diterima atau gugatan para penggugat ditolak, maka dengan mengacu pada maksud ketentuan pasal $192 \mathrm{R}$. Bg., para penggugat dihukum untuk membayar seluruh biaya yang timbul dalam perkara ini.

\section{KESIMPULAN}

Berdasarkan pembahasan diatas, penulis mengambil kesimpulan:

1. Konsep pembagian harta waris dalam hukum KUHPerdata terbagi Ahli Waris Golongan Pertama (I), Ahli Waris Golongan Kedua (II), Ahli Waris Golongan Ketiga (III), Ahli Waris Golongan Keempat (IV). Konsep pembagian harta waris dalam hukum Islam terbagi dalam beberapa bagian yaitu : Hukum bagian waris untuk anak, Hukum Bagian Warisan untuk Orang Tua, Hukum Bagian Waris untuk Duda atau Janda, Hukum Bagian Waris untuk Saudara Seibu Lain Ayah, Hukum Bagian Waris untuk Saudara Sekandung atau Seayah, Bagian Waris Áșabah al-furuḍ, Bagian Ahli Waris Áșabah. 
2. Dalam memutuskan perkara hakim memiliki dasar pertimbangan dalam menyelesaikan perkara sengketa harta waris antara saudara kandung, adapun dasar pertimbangan tersebut secara keseluruhan berpatokan kepada Hukum Islam (kewarisan/ mawaris). Adapun penerapan dari dasar pertimbangan tersebut pada sengketa harta waris antara saudara sekandung, tidak menemui kendala dikarenakan dalam penyelesaian sengketa tersebut diselesaikan secara kekeluargaan. 


\section{DAFTAR PUSTAKA}

Arto, Mukti. Praktek Perkara Perdata pada Pengadilan Agama. Cet. V; Yogyakarta: Pustaka Pelajar, 2004.

Bakry, Muammar M. Akutansi Dasar Mewarisi. Cet. I; Makassar, Alauddin University Perss, 2014.

Dillah, Philips Dan Suratman. Metode Penelitian Hukum. Bandung: Alfabeta, 2015.

F. satriyo Wicaksono. Hukum Waris (Cet; I: Jakarta, Visimedia, 2011).

Haffas, Mustofa dan Salman, H.R. Otje. Hukum Waris Islam. Cet. I; Bandung: PT. Refika Aditama, 2002.

Husein, Harun M. Kasasi sebagai Upaya Hukum. Jakarta: Sinar Grafika, 1992.

Istiqamah, Hukum Waris dan Benda. Makassar: Alauddin University Press, 2012.

Jurdi, Fajlurrahman. Teori Negara Hukum. Malang: Setara Press, 2016.

Kementerian Agama RI. Al-Qur'an dan Terjemahannya. Solo: PT. Tiga Serangkai, 2014. Kompilasi Hukum Islam, Buku II, Pasal 171, huruf a.

Khalik, Subehan. Wasiat Kepada Ahli Waris "Telaah Fikih Dengan Pendekatan Kritik Kesahihan Hadis”. Makassar: Alauddin University Press, 2013.

Lubis, Sulaika. Hukum Acara Perdata Peradilan Agama Di Indonesia. Jakarta: Kencana, 2005.

Mardani, Hukum Kewarisan Islam di Indonesia. Jakarta: Rajawali Pers, 2015.

Muhammad, Rusli, Potret Lembaga Pengadilan Indonesia. Jakarta: PT. Raja Grafindo Persada, 2006.

Mustari, Abdillah. Hukum Waris Perbandingan Hukum Islam Dan Undang-Undang Hukum Perdata Barat. Cet. I; Makassar: Alauddin University Press, 2014.

Ramulyo, M. Idris. Perbandingan Pelaksanaan Hukum Kewarisan Islam Dengan Kewarisan Menurut Kitab Undang-Undang Hukum Perdata. Cet. II; Jakarta: Sinar Grafika, 2000.

Salihima, Syamsulbahri. Perkembangan Pemikiran Pembagian Warisan Dalam Hukum Islam Dan Implementasinya Pada Pengadilan Agama. Cet. I; Jakarta: Kencana, 2015.

Satrio, J. Hukum Waris. Bandung : Alumni, 1992.

Sultan, Lomba. Kekuasaan Kehakiman dalam Ketatanegaraan Islam. Cet. I; Makassar: Alauddin University Press, 2013.

Saebani, Beni Ahmad. Figh Mawaris. Cet. I; Bandung: Pustaka Setia, 2009.

Suma, Muhammad Amin. Keadilan Hukum Islam. Cet. I; Jakarta: Rajawali Pers, 2013.

Syarifuddin, Amir. Hukum Kewarisan Islam. Cet V; Jakarta: Kencana, 2015.

Yayasan Lembaga Bantuan Hukum, Bantuan Hukum Bukan Hak Yang Diberi. Cet. I; Jakarta Pusat :YLBHI, 2013. 